\title{
Students' SMASSE Approaches Beliefs: Activity Based Learning in the Mathematics and Science Classroom
}

\author{
End Salani* \\ Department of Primary Education, Faculty of Education, Private Bag 00702, University of Botswana, \\ Gaborone
}

*Corresponding Author: End Salani, Department of Primary Education, Faculty of Education, Private Bag 00702, University of Botswana, Gaborone

\begin{abstract}
Activity-based learning approaches make lessons less teacher centred and more interactive, thus aiding learners to learn concepts with understanding and actively. It has been however, reported that students' collaboration and interactive skills tended to improve in classes taught with the use of computers compared to those taught through the orthodox methods. Performance in the three year JC results over the last seven years had also been reportedly declining (BEC JC results, 2010-2018) across various subjects in Botswana junior secondary schools, despite the SMASSE program that was introduced in Botswana junior secondary schools in 2006 to facilitate learner centred teaching approaches through activity based learning. It is on the basis of the aforementioned that the purpose of this study was to find out students' views on teachers' use of SMASSE approaches of activity based learning across mathematics and science subjects. The study employed a quantitative survey design and used open ended questions for triangulation purposes. Thirty Form three students formed the sample of this study and it was drawn through simple random sampling technique from one school of the South East Educational Region schools, which was purposively sampled. The data was collected through the use of a questionnaire and coded and analysed through a statistical program called Statistical Package for the Social Sciences (SPSS version 23. Descriptive statistics were used in the data analysis. The data from open ended questions was analysed thematically. The findings from this study revealed that most of the students believed activity based learning helped them to develop cooperative skills and creativity which could possibly result in increased motivation to learn concepts with understanding. The study findings had implications for research and practice as it provides unique and comprehensive data that will lead to insight for curriculum designers, policy implementers and instructional leaders on effective use of activities and other learner centred approaches in the teaching of mathematics and science subjects in schools.
\end{abstract}

Keywords: Secondary education, collaboration and interactive skills, cooperative and creativity, activity based learning, SMASSE approaches.

\section{BACKGROUND}

SMASSE is an acronym for Strengthening of Mathematics and Science in Secondary Education. It uses an activity based approach making use of Activity, Student, Experiment, Improvisation (ASEI) movement and Plan, Do, See and Improve (PDSI) approaches. The approach promotes a learner centered teaching and emphasising a shift from the traditional teacher- talk (lecture) type of approaches to activity based learning pedagogies. The sentiment expressed in the preceding, embodies the view shared by Kamau, Wilson and Thinguri (2014) who indicated that the program activities were centred on the ASEI (Activity, Student, Experiment, and Improvisation) \& PDSI (Plan, Do, See and Improve) approach, which put emphasis on learner-centered preparation and presentation of lessons.

The SMASSE approach is viewed as a tool intended to improve the skills of a teacher in the learner centred environment which in turn provides the student an opportunity to develop useful skills including among others the manipulative skills; critical thinking and innovativeness as enshrined in the Botswana Vision 2036(Botswana, 2016) and the Revised National Policy on Education (RNPE, 1994).

The government of Botswana continues to invest greatly in the provision of quality secondary education. Evidence in support of the preceding argument is the fact that student teachers of 
mathematics and science are given a grant for their tertiary education while other disciplines are loaned and expected to pay back in full amounts expended on them by the government upon completion of their studies (DTEF sponsorship contract Handbook, 2008). Despite that the government is spending a lot in mathematics and science related subjects, students consistently and continuously perform poorly in national examinations (BEC JCE results, 2010-2018) and international comparative studies (TIMSS, 2003; TIMSS, 2007). Persistent under-achievement in mathematics and science has been a concern for some time. Several comparative studies mathematics\& science attainment tests have placed Botswana at the bottom and below the international standard. One such study conducted by Trends in International Mathematics and Science Studies (TIMSS) placed Botswana $3^{\text {rd }}$ position from the bottom in science ahead of Ghana and South Africa (TIMSS, 2003). On the other hand mathematics was placed forth position from the bottom ahead of Saudi Arabia, Ghana and South Africa (TIMSS, 2003). Similarly TIMSS (2007) placed Botswana at position 6 in mathematics and position 3 in science ahead of Kuwait, Elsalvador, Saudi Arabia, Ghana and Qatar and ahead of Qatar and Ghana respectively. In 2007, Botswana saw the establishment of Botswana International University of Science and Technology (BIUST) and this placed a greater demand in the Departments of Secondary Education (DSE) and Teacher Training and Development (TT\&D). The DSE had to produce learners who were suitably qualified entrants for this university while TT\&D had to offer in-service training to teachers to equip them with the requisite skills and knowledge that would enable them to deliver concepts in mathematics and science subjects effectively. It is therefore, on the onus of schools to deliver and produce quality learners in both mathematics and science subjects.

In 1993, SMASSE activities started in Kenya due to poor performance in secondary school mathematics and science (Mwangi \& Mugambi, 2013). Following a survey undertaken in Kenya it revealed that classroom practices were ineffective in view of teaching and learning mathematics and science. Several factors attributed to poor performance in mathematics and science included teacher factors, student factors and teaching \& learning resources and facilities. It was found that teachers had poor mastery of content, poor teaching method and failed to use available resources effectively (http:www.criced.tsuuba.ac.jp). On the other hand, student factors included negative attitudes towards mathematics and science and dislike for mathematics and science subjects (http:www.criced.tsuuba. ac.jp).

SMASSE-WECSA was as result formed as an association of mathematics and science teachers in twenty-nine sub Saharan African countries (http://www.jica.go.jp/topics/news/2013/ku57pq00001mk 98d-att/20140320_01.pdf). This then gave Botswana an opportunity to join the association in 2005 (Botswana SMASSE Manual, 2006).

Over the years, the desire to improve mathematics and science education has seen researchers develop many models and approaches expected to enable teachers to effectively deliver subject content to the learner (http://tech.ed.gov/netp/teaching-prepare-and-connect/; Merrill \& Daugherty, 2010; Swanson, 2001; Kroesbergen \& Van Luit, 2003; Kunsch, Jitendra \& Sood, 2007; Graham, Harris \& Reid, 1992). In Botswana, as earlier indicated we still see a large proportion of students graduating from secondary school system with limited capability in mathematics and science. Research has revealed that several issues contributing to poor performance in mathematics and science were similar in many African countries (Centre for Mathematics \& Science and Technology Education in Africa, CEMASTEA (Miyogo, 2015) Consequently, the concerned countries found it befitting to develop home-grown remedies that could adequately address the quality of classroom activities to enhance student achievement. Therefore, SMASSE's overall goal was to upgrade students' mathematics and science conceptual understanding through provision of INSET to serving teachers. It is on this basis that SMASSE targets classroom effectiveness. As a result the project developed (ASEI) movement, a philosophy with four basic inherent principled guiding SMASSE INSET activities and this is explained below:

\subsection{Activity Focused Teaching/Learning, ASEI}

The "A" aspect of ASEI intends to help teachers appreciate that active learner involvement in teaching and learning process enhances their understanding of mathematics and science thus promoting high retention rate. Here the thrust is to shift from student passive recipient of knowledge 
to an environment where they actively participate in generating knowledge and develop appropriate skills and attitudes.

\subsection{Student Centred Teaching/Learning}

The "S" aspect of ASEI promotes a shift of classroom focus from the teacher as the main or only actor to the learner. Here teachers are made to appreciate the fact that active learner involvement in the teaching/learning process is a key to knowledge and skills acquisition. This therefore, is indicative that teachers should not dominate the teaching/learning process but should act as facilitators.

\subsection{Experiments}

The "E" aspect of ASEI emphasises on shifting from the recipe type experiments (http://www.jica.go. jp/topics/news/2013/ku57pq00001mk98d-att/20140320_01.pdf) to the investigative type that accords learners opportunities to make prediction/hypothesis and verifying them practically. Here learners are encouraged to possibly design their own experiments and appreciate how the activity is linked to the concept so that experiments are not merely done for experiments' sake.

\subsection{Improvisation}

The "I" aspect of ASEI encourages teachers to practice improvisation or innovativeness through utilisation of available materials in the students' immediate environment as a way to stimulate interest and curiosity.

(KENYA SMASSE/SMASE Projects (1998-2013) http://www.jica.go.jp/topics/news/2013/ku57pq00 001mk98d-att/20140320_01.pdf)

In Botswana, the national examination tends to be a factor influencing the methods and approaches teachers adopt to teach. The general tendency it creates is the focus on completion of syllabus as opposed to effective teaching for understanding. As a result important aspects of effective lesson delivery such as planning and evaluation are more often than not ignored. This leaves one to conclude that most teachers prepare planning tools such as lesson plans as a duty to the school management than tools for effective teaching/learning.

\section{PDSI APPROACH}

This is a concept known in SMASSE as an effort for teachers to plan, do, see and improvise. The explanation of the pseudo name is illustrated as thus:

Plan: This is an outline of lesson activity in line with ASEI principles.

Do: This is executing the planned activities

See: evaluation of the process against the plan in terms of effectiveness in achievement of lesson objectives.

Improvise: Enhancing the whole process through the outcome of evaluation. (Mwangi \& Mugambi, 2013: p.51)

\section{LITERATURE REVIEW}

\subsection{Activity Based Learning as a SMASSE Approach}

According to research Activity-based learning entails learners actively engaged in their learning rather than being passive and listening to the teacher directing the instruction (Emaikwu, 2012; Azuka, 2013; Azuka, 2013b). Literature has established several characteristics of activity based learning such as (Lippman, 2016; Agyei\&Voogt, 2016; Laguador, 2014):

- Students are involved in learning activities more than listening, and less emphasis is placed on transmitting information and more on developing student's skills.

- Students are involved in higher-order thinking such as analysis, synthesis, and evaluation.

It is worth noting that activity based classroom tend to encourage learners' active learning. This is emphasised by Laguador (2014) who observed that interactive lessons open doors for cooperation an important aspect of collaboration that creates an environment for better learning experience. 
In view of the preceding characteristics, it calls for teachers to proactively plan interactive lessons with the view of promoting active learning that fosters critical thinking and inquiry skills. This concurs with research finding by Pokhrel (2018) who underscored that teachers should provide learners with opportunities not to just learn mathematics but different skills such as working in a team, leading a group and creativity which are essential for producing a 21 st century skilled learner. All these are provided for through activity based learning as advocated for by the SMASSE approaches to learning mathematics and science subjects in secondary education. In an attempt to justify SMASSE approaches of activity based learning, research has also underscored the benefits of Activity based learning in the teaching and learning process. For example, Emaikwu (2012) emphasised that activity based learning provided for interactive opportunities, thus fostering a critical learner who possesses the $21^{\text {st }}$ century skills (Goos, Stillman \& Vale, 2007). Similarly, Gasser (2011) stressed that classroom teaching must be interactive in such a way that problem based-instruction, and collaborative skills are promoted for meaningful learning to take place. Further research (example given, Agyei \& Voogt, 2016) has stated that activity based learning was learner focussed and this calls for teachers who are in support of progressive methods of teaching and not one who dominate classroom activities. In the same way, Agyei and Voogt (2016) emphasised that activity-based learning approaches make lessons less teacher centred and more interactive, thus aiding learners to learn concepts with understanding and actively.

\subsection{Challenges of Activity Based Learning}

Research has established some challenges associated with activity based teaching and learning in schools. For example, a research by Festus (2013) found that limited class time; long preparation time; the potential difficulty of using active learning in large class; lack of materials, equipment or resources were barriers to effective execution of activity based lessons. Recent research has also established time as one of the factors in the implementation of SMASSE approaches, in essence, Ndirangu, Nyangah and Kimani (2017) pointed out that inadequate time, demotivated teachers and students' indiscipline were detrimental to effective implementation of SMASSE approaches in classroom instruction. On a different note research has also established teachers' attitudes towards SMASSE approaches as barrier or enabler in its implementation. For example, research findings by Makewa, Role and Biego (2011) established that mathematics and science teachers, who tended to have a positive attitude toward the SMASSE student-centered approaches, were most likely to apply the pedagogies brought about by SMASSE approaches. However, Odhiambo, Wanjala, Mwova, Obiero, Gichuru, Nguyo, Matiko, Musau, Wanyonyi and Jalikatu (2013) found that teachers had negative attitudes on the use of ASEI/PDSI principles as opposed to their pupils. This is relevant to my study as perceptions held by learners would be somewhat influenced by their teachers' practices with regard to activity based instruction. Other research (for example, Rotich and Mutisya, 2013) has found that SMASSE approaches have a bearing on learners learning suggesting that a positive minded teacher as a result of the new innovations impacts learners in a positive way. In the same, the preceding findings as presented in the arguments are critical for my study in that the effectiveness of SMASSE approaches will be gauged in light of these attributes (time, limited resources, teachers' and students' attitudes for instance). However, if found to be a challenge in my study, recommendations to ensure proper planning and frequent use of activity- based teaching may see the reduction of these supposed problems.

The introduction of SMASSE approaches in junior secondary schools is in accordance with global learner centred education benefits of use of interactive and hands on activities in mathematics and science instruction which among others includes provision of interactive activity learning based. The foregoing arguments attaches a significant value to activities and classroom learning which is an academic strategy that could form the basis of a learner centred classroom environment as enshrined in the RNPE(1994) recommendation 3.3(c) which states that the objectives of national education at school level is to improve quality instruction. This study therefore intends to establish the students perception about use of activity based learning (SMASSE approaches) in mathematics instruction at junior secondary school level, with the view of establishing good practices geared towards improving the quality of teaching. The findings could provide insight into the challenges that teachers and students face in their pursuit to interact with the limited available mathematics and science activities 

Classroom

and subsequently solutions might be provided with the view of addressing the identified gaps and challenges. The following research questions guided this study:

- What are students' beliefs about SMASSE approaches in the learning processes?

- What recommendations do teachers and students make for effective implementation of SMASE approaches in the classroom instruction?

\section{THEORETICAL FRAMEWORK}

The theoretical framework that underpins this study borrows from Shulman's (1986) pedagogical content knowledge and constructivists' theories of learning. In view of Shulman's (1986) PCK model, effective classroom instruction merges the teacher's content knowledge, knowledge of teaching and learners' learning styles for meaningful learning to take place. It is therefore important to get learners' views on how they are being taught by considering teachers' pedagogical practices during their teaching. On the other hand constructivists theory was used to understand how learner centred instruction (activity) based promote higher order thinking during classroom instructional practices. Furthermore, Constructivists believe that knowledge must be constructed by the learner and Holzer (1994) asserts that it cannot be supplied by the teacher but takes place in context (Gilakjani, Leong, Ishmail, 2013). The theory of constructivism guides much of how children learn and is considered to be one of best observation and scientific study. Under constructivist approaches, learning is an active process in which learners construct new ideas or concepts based on both current and past knowledge (Hodson, 2009). Learners are encouraged to be active constructors of knowledge while the teacher acts as a facilitator. The benefit from the constructivist approach, which is learner-centered in nature, is that the learner retains the information longer because learning is relatable (Skemp, 2006).

It is on the basis of the above that constructivism becomes an instrumental tool for the investigation of the students' beliefs about activity based learning of the mathematics and science subjects. The researchers used constructivists in view of the fact that students' academic challenges are rooted in inappropriate teaching and learning strategies which tend to be teacher dominated, as opposed to learning environments that support multiple perspectives or interpretations of reality, knowledge construction, and context-rich, experience-based activities. This approach is similar to the position of the RNPE (1994), which puts emphasis on learner centered approaches. Within a student-centered curriculum based on student performance, activity based learning provide many opportunities for students and teachers to build knowledge in an engaged setting. As a result, one can use the observed teacher classroom practices to have an in-depth understanding of the causes of those practices as opposed to an interpretation of those pedagogical classroom practices.

\section{Methodology}

In this report, data from quantitative and qualitative methodologies were obtained. A combination of methodologies for data collection included administration of questionnaires to students which were in two parts, open-ended and close-ended questions. The closed-ended component involved several types of statements under the themes or broad categories such as belief systems about the use of SMASSE approaches, the approaches used, and its use as a teaching tool. The qualitative data was collected through students responding to semi-structured open-ended questions. The purpose was to develop a cognitive understanding of the phenomena studied by focusing on the individual experiences in order to develop understanding as the investigator makes knowledge claims based on participants' perspective (Creswell, 2013; Halcomb\& Hickman, 2015).

The school had been involved with the SMASSE programme since its inception in Botswana schools in 2007. These made this school suitable for such a research study. Only the Form 3 students were targeted as they had been subjected or at least taught by teachers who have been advocating or practising the programme's principles for longer. Their longevity in school, made them suitable as they would have formed some form of impression about the programme, about the teachers, the programme's relevance and how much it is manifesting in classrooms, as well as how teachers are employing that in their day to day teaching and learning activities. The students were requested to volunteer to participate in completing the questionnaire since they were the ones who were aware of the strengths, challenges and weaknesses of the programme or of their teachers. Altogether 30 students completed the questionnaire. 
To bring familiarity with the content of the data notes (open-ended statements), it was important to read and re-read this material so as to make sense and bring coherence to all the text. This process ran concurrently with the typing of the reflection notes. Broader findings were selected during reading and linked to the wider intentions of SMASSE approaches. These provided information about the teachers' operations that is what the learners viewed the teachers as doing in their classrooms and in a way giving a guide as to what is happening in the school.

\section{RESUlt ANALYSIS}

Tables $1 \& 2$ and figures $1 \& 2$ below present the results from the students' survey which speaks to their beliefs about use of SMASSE approaches, frequency of utilisation of SMASSE strategies and beliefs about existing conditions under which SMASSE approaches are used in the learning processes.

Table1: Students beliefs about use of SMASSE approaches in the learning processes

\begin{tabular}{|c|c|c|c|c|c|c|c|}
\hline \multicolumn{8}{|c|}{ Descriptive Statistics } \\
\hline & $\mathrm{N}$ & Range & Minimum & Maximum & & Iean & Std. Deviation \\
\hline & Statistic & Statistic & Statistic & Statistic & Statistic & Std. Error & Statistic \\
\hline $\begin{array}{ll}\text { SMASSE } & \text { enhance } 3 \\
\text { collaboration } & \end{array}$ & & 2 & 3 & 5 & 4.60 & 0.103 & 0.563 \\
\hline \begin{tabular}{|lrr} 
SMASSE & provides & all3 \\
information & needed & for \\
learning & & \\
\end{tabular} & & 3 & 2 & 5 & 4.43 & 0.171 & 0.935 \\
\hline $\begin{array}{l}\text { SMASSE makes students to } 3 \\
\text { be centre of learning }\end{array}$ & & 2 & 3 & 5 & 4.50 & 0.125 & 0.682 \\
\hline \begin{tabular}{|ll} 
SMASSE & promotes 3 \\
interactive and & meaningful \\
environment
\end{tabular} & & 1 & 4 & 5 & 4.73 & 0.082 & 0.450 \\
\hline $\begin{array}{l}\text { SMASSE allows for } 3 \\
\text { discovery of new } \\
\text { through hands on }\end{array}$ & & 1 & 4 & 5 & 4.83 & 0.069 & 0.379 \\
\hline $\begin{array}{ll}\text { SMASSE } & \text { improves } 3 \\
\text { understanding and retention }\end{array}$ & & 1 & 4 & 5 & 4.80 & 0.074 & 0.407 \\
\hline $\begin{array}{l}\text { SMASSE makes teachers } 3 \\
\text { biased and prohibitive }\end{array}$ & & 3 & 2 & 5 & 3.97 & 0.169 & 0.928 \\
\hline $\begin{array}{l}\text { SMASSE increases } 3 \\
\text { motivation and participation }\end{array}$ & & 2 & 3 & 5 & 4.77 & 0.092 & 0.504 \\
\hline $\begin{array}{l}\text { SMASSE enhances working } 3 \\
\text { relations }\end{array}$ & & 1 & 4 & 5 & 4.80 & 0.074 & 0.407 \\
\hline \begin{tabular}{|lcc} 
SMASSE & makes & student 3 \\
over-reliant & on & teacher \\
information & & \\
\end{tabular} & & 4 & 1 & 5 & 2.10 & 0.227 & 1.242 \\
\hline $\begin{array}{ll}\text { SMASSE increase stress } 3 \\
\text { and anxiety levels }\end{array}$ & & 3 & 2 & 5 & 4.40 & 0.170 & 0.932 \\
\hline $\begin{array}{l}\text { SMASSE is helpful in } 3 \\
\text { preparation for exams }\end{array}$ & & 2 & 3 & 5 & 4.80 & 0.088 & 0.484 \\
\hline $\begin{array}{l}\text { SMASSE makes classroom } 3 \\
\text { noisy and rowdy }\end{array}$ & & 4 & 1 & 5 & 3.57 & 0.252 & 1.382 \\
\hline $\begin{array}{l}\text { SMASSE activities are } 3 \\
\text { inadequate and irrelevant }\end{array}$ & & 1 & 4 & 5 & 4.87 & 0.063 & 0.346 \\
\hline
\end{tabular}

The questionnaire sought to establish students' beliefs about the use of SMASSE approaches in their learning processes by asking questions on the following:

- Enhance student collaboration and interactive environment

- Makes teachers passive, rigid and not allowing students to explore other methods

- Over reliant on information from teacher than prescribed textbook

The results show that the majority of the respondents agree that SMASSE approaches were useful for their learning as it enhanced collaboration among students and also the approach allowed them the opportunity to discover new things through hands on activities. This is shown in table 1 where the 
mean responses for most items ranged above 4, indicating a positive response to the items. In support of the preceding statement, one of the respondents stated that "The SMASSE approaches help us to improve our understanding and help us to remember activity we used or we were doing the last time when is time for examinations, quiz or test". Students further reiterated on the need to extend the SMASSE approaches to other subjects other than mathematics and science as they felt the approach helps them to understand more and do things for themselves. For example the students pointed out that as they performed experiments they are able to recall all the activities without any difficulty. The questionnaire further wanted to establish the frequency of SMASSE strategies in learning activities by asking questions on:

- Frequency of use of SMASSE approaches for tutorial and remedial purposes

- Frequency of use of SMASSE approaches for quizzes and group activities

- Frequency of use of SMASSE approaches for discovery and consolidation of concepts

- Frequency of use of SMASSE approaches for drill and practice (See table 2 below)

Table2: Frequency of utilisation of SMASSE approaches in learning activities

\begin{tabular}{|l|l|l|l|l|l|l|l|l|}
\hline \multicolumn{2}{|c|}{ Descriptive Statistics } \\
\hline & \multicolumn{2}{|c|}{$\mathrm{N}$} & Range & Minimum & Maximum & \multicolumn{2}{|c|}{ Mean } & Std. Deviation \\
\cline { 2 - 9 } & Statistic & Statistic & Statistic & Statistic & Statistic & Std. Error & Statistic \\
\hline $\begin{array}{l}\text { SMASSE approaches utilised } 30 \\
\text { in quizzes }\end{array}$ & 4 & 1 & 5 & 3.90 & .205 & 1.125 \\
\hline $\begin{array}{l}\text { SMASSE approaches utilised } 30 \\
\text { in group work }\end{array}$ & 2 & 3 & 5 & 4.20 & .162 & 0.887 \\
\hline $\begin{array}{l}\text { SMASSE approaches utilised } 30 \\
\text { in introduction of new } \\
\text { concepts }\end{array}$ & 4 & 1 & 5 & 3.80 & .211 & 1.157 \\
\hline $\begin{array}{l}\text { SMASSE approaches utilised } 30 \\
\text { in remedial purpose }\end{array}$ & 4 & 1 & 5 & 2.40 & .218 & 1.192 \\
\hline $\begin{array}{l}\text { SMASSE approaches utilised 30 } \\
\text { in consolidation of concepts }\end{array}$ & 4 & 1 & 5 & 3.70 & .215 & 1.179 \\
\hline $\begin{array}{l}\text { SMASSE approaches utilised } 30 \\
\text { in discovery learning }\end{array}$ & 4 & 1 & 5 & 3.90 & .232 & 1.269 \\
\hline $\begin{array}{l}\text { SMASSE approaches utilised } 30 \\
\text { in drill and practice }\end{array}$ & 4 & 1 & 5 & 3.40 & .218 & 1.192 \\
\hline $\begin{array}{l}\text { SMASSE approaches utilised } 30 \\
\text { in tutorials }\end{array}$ & 4 & 1 & 5 & 2.47 & .270 & 1.479 \\
\hline
\end{tabular}

The results as shown in table 2 above indicates that the majority of the respondents revealed an often response on all items except for two items where they indicated that teachers rarely used SMASSE approaches for remedial and tutorial purposes. The mean response ranged from 3 indicating that teachers sometimes or often used SMASSE approaches for discovery, drill and practice and group work activities. This affirmative responses is indicative that teachers employed a variety of teaching approaches ranging from drill and practice to discovery methods of teaching. However, the negative response for items on remedial and tutorial purposes clearly shows that teachers were not according those opportunities for students with learning needs and there were no opportunities to enrich those students who are high achievers (see Table 2). These findings, therefore, send a clear signal of the need to introduce a remedial teaching programme as a way of increasing learning opportunities to students in mathematics and science, thus contributing to realisation of quality education as enshrined in ETSSP (2015-2020) Republic of Botswana, 2015). Finally, the questionnaire wanted to find out the students' beliefs about existing conditions on the use of SMASSE approaches in the learning process.

The results from figure 1 above show that the majority of the respondents revealed their agreement with that there was inadequate time for effective use of SMASSE in classroom instruction and that there was inadequate resources to promote the use of SMASSE in the teaching of mathematics and science in their school. However, the students refuted that SMASSE affected the completion of the syllabus and also indicated that SMASSE was valuable to the mastery of subject matter in the learning process. It is quite evident from the findings that there is an urgent need for policy makers, regional 
education officers and school authorities to support schools with adequate resources for effective implementation of SMASSE approaches as students valued the approach, a good move towards realisation of quality instruction in mathematics and science subjects. One of the students stated that "SMASSE need more time because they are slow learners so they need more time to be helped...There are not enough classroom activities to cater for individual needs".

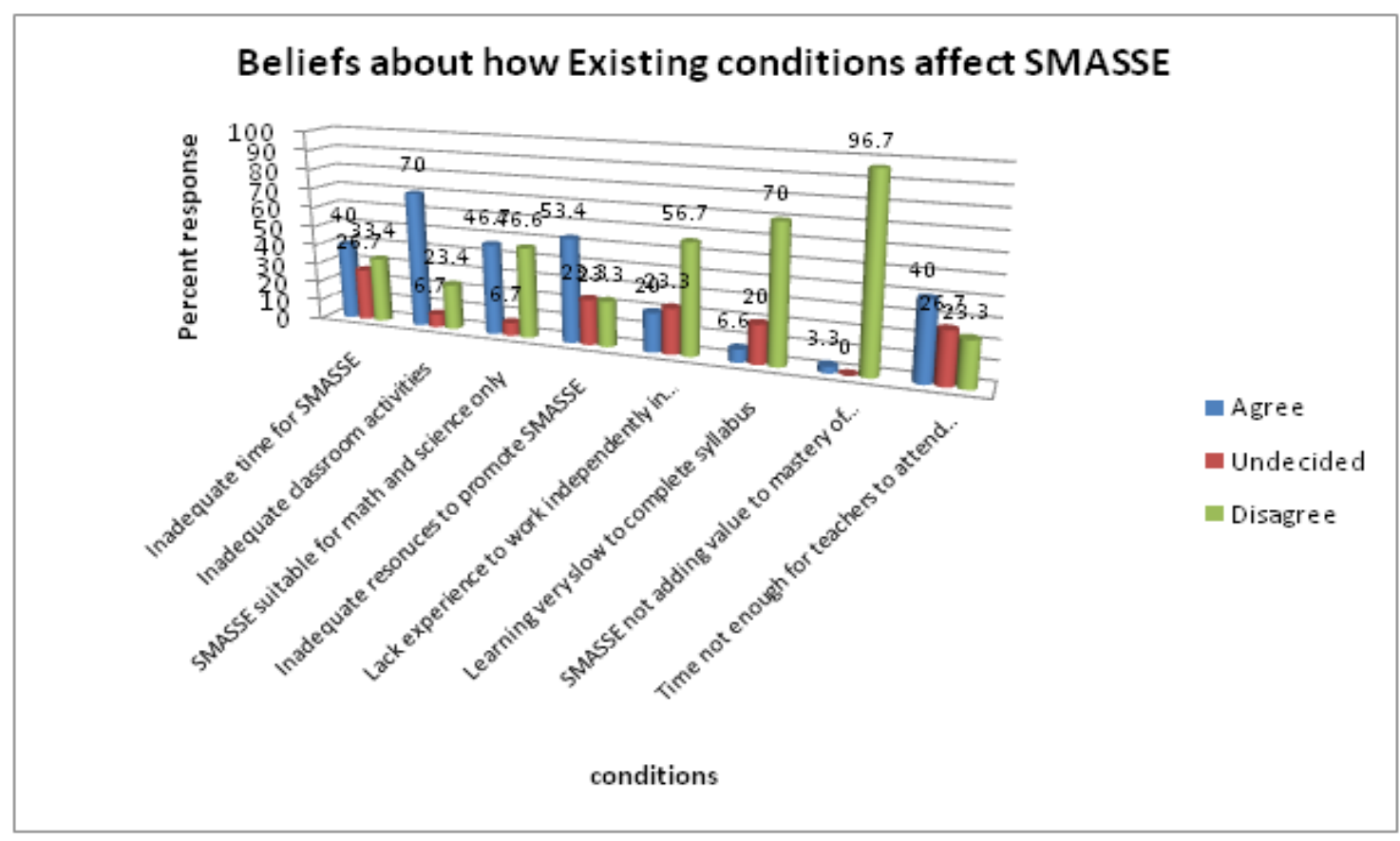

Figure1: Students beliefs about existing conditions and SMASSE use

\section{Discussions AND CONClusions}

This section summarises the findings according to the following research questions:

\subsection{Q1. Students Beliefs about SMASSE Approaches in the Learning Processes}

The findings from this study revealed that most of the students had a positive attitude towards activity based learning which came as a result of SMASSE approaches implementation. Students felt activity based learning promoted an effective classroom learning environment in terms of enhancing collaborative skills, discovery experiences and motivating them to learn new things better through hands on activities. This finding concurs with findings from research elsewhere (eg. Emaikwu, 2012; Gasser, 2011; Festus, 2013) who emphasised that activity based learning was critical for learners as they tend to understand mathematics concepts better and have higher retention when they actively participate in the lesson. This is a ground breaking attitude displayed by learners implying that teachers should take advantage of all this and move away from traditional instruction to activity based instruction as advocated by SMASSE approaches. Students further indicated that learning through activities could enhance their creativity, a skill essential for meaningful learning. Different from the preceding argument, most of the students also felt that they were not accorded enough opportunities to use activities in other aspects of learning as they felt teachers did not accord those opportunities to use activities for remediation and or tutorial purposes.

On a positive note they felt activity based learning was critical as it empowered them with relevant creativity skills and adequate experience that could facilitate their learning of concepts with understanding. The findings further revealed that students felt that they had limited access to activities as their learning needs were not fully addressed and this they said impacted negatively on them especially those who were slow in learning and believed could learn better if they interacted with concrete objects. The aforementioned arguments are supported by several research findings (Rathva,2012; Festus, 2013;Pokhrel, 2016) who found that activities make mathematics and science teaching and learning more joyful and effective. This as a result calls for a paradigm shift from predominantly centred methods to learner centred pedagogies in order to create a learning environment that is process driven as opposed to result oriented. 


\subsection{Q2. What Recommendations do Teachers and Students Make for Effective Implementation of SMASSE Approaches in the Classroom Instruction?}

The findings revealed the following recommendations made by students as strategies intended to improve teaching and learning through activity based learning as provided for by SMASSE approaches:

Students deplored lack of time as they felt the timetabled time was inadequate to proffer them an opportunity to learn higher order skills through activity based learning. They further stressed that the number of activities given to them was limited, thus depriving the slow learners opportunities to interact through hands on which they believe could reinforce their understanding of concepts. For this reason, students pointed out on the need to have more time allocated and that the laboratories should be availed to them frequently for them to do some experimentation that would bridge the gap between theory and practice. Another significant point raised by students is on the issue of using activities for remedial and group work purposes, thus calling for educational reform to expedite the establishment of remedial programmes which tend to put more emphasis on learning by doing which is what students seem to be calling for.

\section{CONCLuSion}

The study found that most of the students valued activity based learning which is SMASSE compliant as useful for their learning as it enhanced collaboration among students and also the approach allowed them the opportunity to discover new things through hands on activities. It was further revealed that students felt that SMASSE approaches were minimally utilised for discovery, drill and practice and group work activities. There were some students who felt strongly that teachers did not provide activities for remedial and tutorial purposes. It is a result conclusive that teachers were cognisant of varied learning strategies but did not use activity based learning in critical activities such as remediation and group activities which are important in addressing varied learning needs. These findings, therefore, send a clear signal for the need to introduce a remedial teaching programme in schools as a way of increasing learning opportunities to students in mathematics and science, thus contributing to realisation of quality education. In this manner, the continued practices will strengthen the use of activity-based teaching and learning processes of junior secondary mathematics and science in schools, thus supporting SMASSE approaches which have been found to produce results where resources and large class sizes are a challenge.

In addition, Most of the students agreed that limited time and lack of resources characterised their mathematics and science classroom learning. This suggests that the time allocated to mathematics and science was not adequate to satisfy learners' academic needs, thus calling for a skilful teacher who would effectively employ the right pedagogical skills to implement the SMASSE approaches to students' satisfaction. While considering the above observation, it is clear that most of the students enjoyed learning through hands on activities as provided for by SMASSE approaches. It is therefore important for teachers of mathematics and science to create activities and improvise using the available materials in the students' immediate environment in order to foster an active based teaching and learning environment.

\section{RECOMMENDATIONS}

With regard to the research findings and conclusions drawn from the study, certain areas need to be re-considered for they significantly affect the effective use of activity based learning in classroom instruction. The researchers have categorised recommendations by stakeholders.

\section{- Present and Future Teachers}

Mathematics and science teachers should learn and embrace activity based instruction as an alternative classroom instructional practice so as to meet the $21^{\text {st }}$ century learners existing in the classrooms of today. This would enhance teachers' ability to explore the relationship between pedagogy and activity instructional materials.

\section{- School Heads snd Senior Teacher Academics}

The school management should play a leading role in ensuring the effective implementation of ASEIPDSI lesson plans and teaching in the mathematics and science school curriculum. This could be 

Classroom

achieved through developing infusion strategies and conducting planned monitoring and evaluation of the same for effective management of the programme. Furthermore, teachers should be supported in terms of proper planning and instructional support to effectively incorporate activity based learning in their classroom teaching. The school management should ensure that there is adequate funding for instructional materials that are activity based supportive.

\section{- Future Research}

There should be a sampling from a much broader spectrum of students who are exposed to SMASSE approaches of learning at secondary education level. There is also a need to survey perceptions of school management and teachers on the implementation of SMASSE approaches in their respective schools. In pursuit of better strategies to ensure effective implementation of SMASSE approaches the priority levels of activity based learning in secondary school mathematics and science curriculum needs to be established and to what level of importance it is to capacitate teachers in preparation for the implementation of activity based SMASSE approaches.

\section{REFERENCES}

[1] Agyei, D.D. and Voogt, J.M. (2016). Pre-service mathematics teachers' learning and teaching of activitybased lessons supported with spreadsheets. Technology, pedagogy and Education, 25(1), pp.39-59.

[2] Azuka, B.F. (2013). Attitude of secondary school mathematics teachers towards the teaching of school mathematics in Nigeria. Journal Mathematical Sciences Education, 2(1), pp 181-191 Azuka, B.F. (2013b). Activity- based learning strategies in the mathematics classrooms. Journal of Education and Practice, 4(13), 2013, pp 8-14

[3] Botswana (1994).The Revised National Policy on Education. Gaborone: Government Printers.

[4] Botswana (2006).SMASSE Training Manual. Gaborone: Government Printers.

[5] Botswana Examination Council (2010-2018). Press release. Junior-certificate-examination-jce-pressrelease. Available from: http://www.bec.co.bw/ junior secondary [Accessed on 16th April 2019].

[6] Botswana (2015).Education and Training Sector Strategic Plan (ETSSP 2015-2020). Gaborone: Government Printers.

[7] Creswell, J.W. (2013). Qualitative Inquiry \& Research Design: Choosing among Five Approaches. Los Angeles, CA: Sage.

[8] Emaikwu, S. O. (2012). Assessing the relative effectiveness of the three teaching methods in the measurement of students' achievement in mathematics. Journal of Emerging Trends in Educational Research and Policy Studies (JETERAPS), 3(4).Pp 479-486.

[9] Festus, A.B. (2013). Activity-based learning strategies in the mathematics classrooms. Journal of Education and Practice, 4(13), pp.8-14.

[10] Gasser, K.W. (2011). Five ideas for 21st century math classrooms.American Secondary Education, pp.108-116.

[11] Gilakjani, A. P., Leong, L. M. \& Ismail, H.N. (2013). Teachers' Use of Technology and Constructivism. International Journal of Modern Education and Computer Science, 4, pp. 49-63. Online May 2017 in MECS (http://www.mecs-press.org/) DOI: 10.5815/ijmecs.

[12] Goos, M., Stillman, G. and Vale, C. (2007).Teaching secondary school mathematics: Research and practice for the 21 st century. Allen \&Unwin.

[13] Graham, S., Harris, K. R., \& Reid, R. (1992).Developing self regulated learners. Focus on Exceptional Children, 24(6), 1-16.

[14] Halcomb, E.J. and Hickman, L. (2015).Mixed methods research.

[15] Hodson, D. (2009). Teaching and learning about science: Language, theories, methods, history, traditions and values. The Netherlands: Sense Publishers.

[16] Holzer,S.(1994). "From Constructivism to Active Learning," The Innovator, no.2.

[17] Kamau, K.J., Wilson, K. \&Thinguri, R. (2014).An Evaluation of the Effectiveness of SMASSE Program in Performance of Science and Mathematics in primary Schools in Kenya.International journal of Educational Research, Vol. 2(6), pp.1-10. Retrieved on 03 August, 2015 from http://www.ijern.com/ journal/June-2014/01.pdf

[18] Kroesbergen, E. H., \& Van Luit, J. E. H. (2003).Mathematics interventions for children with special educational needs. Remedial and Special Education, 24(2), 97-114.

[19] Kunsch, C., Jitendra, A., \&Sood, S. (2007). The effects of peer mediated instruction in mathematics for students with learning problems: A research synthesis. Learning Disabilities Research \& Practice, 22(1), 1-12. 
[20] Laguador, J.M. (2014). Cooperative learning approach in an outcomes-based environment. International Journal of Social Sciences, Arts and Humanities, 2(2), pp.46-55.

[21] Lippman, P.(2016). Activity Based Learning Environments. https://placescreatedforlearning.com/activitybased-learning-environments/

[22] Makewa, L.N., Role, E.M. and Biego, S. (2011). Teachers' attitude towards strengthening mathematics and science in secondary education through in-service education and training (SMASSE-INSET) Project in Nandi Central District, Kenya. International Journal of Education and Social Sciences (IJESS), 1(4), pp.1-5.

[23] Martin, M.O., Mullis, I.V.S., \& Foy, P. (with Olson, J.F., Erberber, E., Preuschoff, C., \&Galia, J.). (2008). TIMSS 2007 International Science Report: Findings from IEA's Trends in International Mathematics and Science Study at the Fourth and Eighth Grades. Chestnut Hill, MA:Boston College. Retrieved on 03 August, 2015 from http://timssandpirls.bc.edu/TIMSS2007/mathematicsreport.html.

[24] Martin, M.O., Mullis, I.V.S., Gonzalez, E.J., \&Chrostowski, S.J. (2004).TIMSS 2003 International Science Report: Findings from IEA's Trends in International Mathematics and Science Study at the Fourth and Eighth Grades. Chestnut Hill, MA: Boston College. Retrieved on 03 August, 2015 from http://timssand pirls.bc.edu/timss2003i/scienceD.html.

[25] Merrill, C \& Daugherty, J. (2010). STEM Education and Leadership: A Mathematics and Science Partnership Approach. Journal of Technology Education, Vol.21 (2), pp. 1-9. Retrieved on 03 August, 2015 from http://scholar.lib.vt.edu/ejournals/JTE/v21n2/merrill.html.

[26] Miyogo, N.D. (2015). Strategy Implementation Practices At Center For Mathematics, Science And Technology Education In Africa (CEMASTEA) In Kenya (Doctoral Dissertation, School Of Business, University of Nairobi).

[27] Mullis, I.V.S., Martin, M.O. \& Foy, P. (2008).TIMSS 2007 International Mathematics Report.Findings from IEA's Trends in International Mathematics and Science Study at the fourth and eighth grades. Chestnut Hill, MA: Boston College. Retrieved on 03 August, 2015 from http://timssandpirls.bc.edu/ TIMSS2007/mathematicsreport.html

[28] Mullis, I.V.S., Martin, M.O., Gonzalez, E.J., \&Chrostowski, S.J. (2004).TIMSS 2003 International Mathematics Report: Findings from IEA's Trends in International Mathematics and Science Study at the Fourth and Eighth Grades. TIMSS \& PIRLS International Study Center: Boston College. Retrieved on 03 August, 2015 from http://timss.bc.edu/PDF/t03_download/T03INTLMATRPT.pdf.

[29] Musau, H.P., Wanyonyi, M.N. and Jalikatu, M. (2013). An Evaluation of Asei-Pdsi Teaching Approach in Mathematics in Public Primary Schools In Kisumu West Sub County, Kenya.

[30] Mwangi, N.I. and Mugambi, M. (2013).Evalaution of strengthening of mathematics and science in secondary education (SMASSE) Program. A case study of Murang'a South District, Kenya. International Journal of Education Learning and Development, 1(1), pp.46-60.

[31] Ndirangu, C., Nyangah, G. and Kimani, G. (2017). The level of implementation of ASEI/PDSI classroom practices in science subjects: A case of SMASSE project, Kenya. International Journal of Learning, Teaching and Educational Research, 16(5), pp.118-140.

[32] Odhiambo, O.B., Wanjala, J.M., Mwova, J.P., Obiero, B.O., Gichuru, B.M., Nguyo, G.N., Matiko, G., Musau, H.P., Wanyonyi, M.N. and Jalikatu, M. (2013). An Evaluation of Asei-Pdsi Teaching Approach in Mathematics In Public Primary Schools In Kisumu West Sub County, Kenya.

[33] Website http:www.criced.tsuuba.ac.jp

[34] Pokhrel, T.R., 2018. Activity Based Mathematics Instruction: Experiences in Addressing the 21st-Century Skills. Journal of Mathematics Education, 11(1), pp.46-61.

[35] Rathva, P. (2012). Teaching mathematics through activities. Retrieved from http://www.ncert.nic.in/pdf_ files/teaching\%20mathematics(Parul\%20 Rathva).pdf.

[36] Republic of Botswana (2006). SMASSE Training manual.

[37] Republic of Botswana (2008).DTEF sponsorship contract Handbook.

[38] Republic of Botswana (2008). DTEF sponsorship contract Handbook. Gaborone: Government Printers.

[39] Republic of Botswana (2016).Vision 2036 Handbook.

[40] Rotich, S.K. and Mutisya, S., 2013. Evaluation of capacity development programs in Kenya: a case of SMASSE INSET for science teachers.

[41] Shulman, L.S., 1986. Those who understand: Knowledge growth in teaching. Educational researcher, 15(2), pp.4-14.

[42] Skemp, R.R., 2006. Relational understanding and instrumental understanding. Mathematics teaching in the middle school, 12(2), pp.88-95. 
[43] Swanson, H. L. (2001). Searching for the best model for instructing students with learning disabilities. Focus on Exceptional Children, 34(2), 1-15.

[44] Website http:www.criced.tsuuba.ac.jp

[45] Website http://www.jica.go.jp/topics/news/2013/ku57pq00001mk98d-att/20140320_01.pdf

[46] Website http://www.jica.go.jp/topics/news/2013/ku57pq00001mk98d-att/20140320_01.pdf).

[47] Website http://tech.ed.gov/netp/teaching-prepare-and-connect/

Citation: End Salani. "Students' SMASSE Approaches Beliefs: Activity Based Learning in the Mathematics and Science Classroom". International Journal of Humanities Social Sciences and Education (IJHSSE), vol. 6, no.12, 2019, pp. 153-164. doi: http://dx. doi.org/10.20431/2349-0381.0612014.

Copyright: (C) 2019 Authors. This is an open-access article distributed under the terms of the Creative Commons Attribution License, which permits unrestricted use, distribution, and reproduction in any medium, provided the original author and source are credited. 